\title{
Pengaruh Karakteristik Tujuan Anggaran Terhadap Kinerja Aparat Pemerintah Daerah di Provinsi Daerah Khusus Ibukota Jakarta
}

Hadi Kurnia ${ }^{1}$

${ }^{1}$ Universitas Pancasila, Jl. Srengseng Sawah, Jagakarsa, Jakarta Selatan, 12640

INFO ARTIKEL

JEL Classsification:

M38

L25

M48

Keywords:

participation,

feedback, apparatus

perfirmance,

explication of budget

objectives, budget

evaluation.

\section{$A B S T R A C T$}

The use of budgets to control, evaluate communications, and improve coordination is an activity in the preparation of the budget. The purpose of this study was to determine the effect of budgetary participation, clarity of budget objectives, budget evaluation, budgetary feedback and difficulty in achieving budget objectives on the performance of local government apparatus. The sample of this research is 41 employees of Local Government Work Unit (SKPD) of Provincial Government of Special Capital Region of Jakarta. Perngujian data quality is done with the validity and reliability test followed by the classical assumption test. Hypothesis test is done by multiple regression test. The results showed that participation and difficulty in achieving the objectives did not affect the performance of the government apparatus. Feedback, budget evaluation and objective clarity proved to have an effect on the performance of the apparatus. The results of this study are expected to contribute in the evaluation of personnel performance and human resource management in the provincial government especially DKI Jakarta.

\section{A B S T R A K}

Penggunaan anggaran untuk melakukan pengendalian, evaluasi komunikasi, dan meningkatkan koordinasi merupakan aktivitas dalam penyusunan anggaran. Tujuan penelitian ini adalah untuk mengetahui pengaruh partisipasi anggaran, kejelasan tujuan anggaran, evaluasi anggaran, umpan balik anggaran dan kesulitan pencapaian tujuan anggaran terhadap kinerja aparat pemerintah daerah. Sampel penelitian adalah 41 pegawai Satuan Kerja Pemerintah Daerah (SKPD) Pemerintah Provinsi Daerah Khusus Ibukota Jakarta. Perngujian kualitas data dilakukan dengan uji validitas dan reliabilitas dilanjutkan dengan uji asumsi klasik. Uji hipotesis dilakukan dengan uji regresi berganda. Hasil penelitian menunjukkan partisipasi dan kesulitan pencapaian tujuan tidak mempengaruhi kinerja aparat pemerintah. Umpan balik, evaluasi anggaran dan kejelasan tujuan terbukti berpengaruh terhadap kinerja aparat. Hasil penelitian diharapkan dapat memberikan kontribusi dalam evaluasi kinerja aparat dan tata kelola sumber daya manusia di Pemerintah Provinsi khususnya DKI Jakarta.

*Email Korespondensi: 'hadikurnia7275@yahoo.com 


\section{Pendahuluan}

Penganggaran merupakan bagian dari proses perencanaan yang mana perencanaan merupakan salah satu siklus manajemen organisasi. Anggaran mengungkapkan apa yang akan dilakukan di masa yang akan datang (Bastian, 2006). Anggaran sebagai rencana operasional yang dinyatakan dalam satuan uang dari suatu organisasi dimana disuatu pihak menggambarkan perkiraan biaya (pengeluaran) dan dipihak lain menggambarkan perkiraan pendapatan (penerimaan) guna menutupi pengeluaran tersebut, untuk suatu periode tertentu yang umumnya satu tahun Anggaran sebagai rencana operasional yang dinyatakan dalam satuan uang dari suatu organisasi dimana disuatu pihak menggambarkan perkiraan biaya (pengeluaran) dan dipihak lain menggambarkan perkiraan pendapatan (penerimaan) guna menutupi pengeluaran tersebut, untuk suatu periode tertentu yang umumnya satu tahun (Syafrizal, Said Herry\&Aknawal, Cut 2011). Anggaran menjadi alat akuntansi manajerial yang umum digunakan dengan 2 fungsi utama, yaitu (1) sebagai alat untuk menjalankan tujuan melalui perencanaan dan pengkoordinasian aktivitas perusahaan dan (2) sebagai benchmark untuk mengevaluasi kinerja aktual.

Penggunaan anggaran untuk melakukan pengendalian, evaluasi komunikasi, dan meningkatkan koordinasi merupakan aktivitas dalam penyusunan anggaran (Hansen dan Mowen, 2000). Di dalam proses penyusunan anggaran terdapat berbagai pertimbangan yang perlu diperhatikan di dalam proses penyusunan anggaran. Mengabaikan berbagai faktor eksternal dan internal di dalam proses penyusunan anggaran merupakan jaminan kegagalan realisasi anggaran di dalam pemerintah (Rai, 2008:14). Oleh karena itu, faktor-faktor yang eksternal dan internal harus diperhatikan dalam penyusunan anggaran. Proses penyusunan anggaran pemerintah dimulai pada tingkat Kementerian dengan Rencana kerja dan Anggran Kementerian Negara/Lembaga (RKA-
KL). Dengan berpedoman pada Renja-KL, masing-masing kementerian/lembaga menyusun RKA-KL yang berisi program dan kegiatan Kementerian/lembaga, berserta anggaran yang diperlukan untuk melaksnakannya. Karena pada dasaranya anggaran merupakan sebagai alat akunbuilitas, manajemen dan kebijakan ekonomi yang mempunyai pencapaian anggaran yang baik.

Mardiasmo (2005: 63) menyatakan terdapat beberapa alasan, pentingnya anggaran sektor publik yaitu : (1) anggaran merupakan alat bagi pemerintah untuk mengarahkan pembangunan sosial-ekonomi, menjamin kesinambungan, dan meningkatkan kualitas hidup masyarakat, (2) anggaran diperlukan karena adanya masalah keterbatasan sumber daya (Scarcity of resources), pilihan (choise) dan trade offs (3) anggaran diperlukan untuk meyakinkan bahwa pemerintah telah bertanggung jawab terhadap rakyat. Sehingga dalam hal ini anggaran publik merupakan instrumen pelaksanaan akuntabilitas publik oleh lembaga-lembaga publik yang ada. Anggaran Pendapatan dan Belanja Daerah (APBD) di Indonesia disusun berdasarkan pendekatan kinerja, yaitu suatu anggaran yang mengutamakan upaya pencapaian hasil kerja atau output dari perencanaan alokasi biaya atau input yang ditetapkan. Berdasarkan pendekatan kinerja, APBD disusun harus pada sasaran tertentu yang hendak dicapai dalam satu tahun anggaran. Karena Pencapaian anggaran yang baik dalam suatu organisasi pemerintah berpatokan pada karateristik tujuan anggaran yang ada . Ada faktor yang perlu dipertimbangkan yaitu interes pribadi dan karakteristik tujuan anggaran sebagai unsur penunjang keberhasilan pelaksanaan anggaran. Menurut Kenis (dalam Syafrizal \& Aknawal, 2011:2) ada 5 dimensi yang termasuk dalam karakteristik tujuan anggaran yaitu (1) partisipasi penyusun anggaran, (2) kejelasan tujuan anggaran, (3) umpan balik anggaran, (4) evaluasi anggaran, dan (5) tingkat kesulitan pencapaian tujuan anggaran.

Menurut Aimee \& Carrol (Jalaudin \& Bahri, 2009) menemukan mekanisme 
input partisipasi warga Negara mempunyai pengaruh langsung pada keputusan anggaran. Keuntungan penggunaan input warga negara kedalam operasional kota bisa membantu dewan dalam menjalankan tanggung jawabnya untuk mewakili konstituen dan memberikan visi dan arahan kebijakan jangka panjang. Kejelasan tujuan anggaran menunjukkan luasnya tujuan anggaran yang dinyatakan secara spesifik dan jelas, dan dimengerti oleh siapa saja yang bertanggung jawab. sedangkan menurut Kennis (dalam Jalaudin \& Bahri, 2009) mengungkapakan bahwa manajer memberi reaksi positif dan secara relative sangat kuat untuk meningkatkan kejelasan tujuan anggaran. Manajemen tingkat atas dapat meningkatkan kepuasan kerja, menurunkan ketegangan kerja, dan memperbaiki anggaran yang dihubungkan dengan sikap, kinerja anggaran, dan efisiensi biaya menajer tingkat bawah secara signifikan meningkatkan kejelasan dan ketegangan tujuan anggaran mereka. Karateristik tujuan anggran dalam umpan balik terhadap sasaran anggaran yang dicapai adalah variabel penting yang memberikan motivasi kepada manajer, jika anggota organisasi tidak mengetahui hasil yang diperoleh dari upayanya untuk mencapai sasaran maka ia tidak mempunyai dasar untuk merasakan kesuksesan atau kegagalan dan tidak ada inisiatif untuk menunjukkan kinerja yang lebih baik, dan pada akhirnya menjadi tidak puas. Setiap pencapaian organisasi terkadang ada yang sesuai dengan harapan dan ada juga yang tidak memenuhi harapan.

Mega dan Endang (2015) menyatakan dalam penelitiannya partisipasi anggaran memiliki pengaruh signifikan dan positif terhadap kinerja manajerial. Kondisi ini ditunjukkan dengan adanya tingkat signifikansi variabel tersebut dibawah $\alpha=5 \%$. Semakin tinggi partisipasi anggaran akan semakin meningkatkan kinerja manajerial.

Mutmainah dan Ikhsan (2013) dalam penelitiannya karakteristik tujuan anggaran berpengaruh positif terhadap kinerja manajerial, hal ini berarti bahwa semakin baik karakterisitk tujuan anggaran akan semakin meningkat kinerja manajerial

Masalah lain yang tidak kalah pentingnya dalam upaya memperbaiki proses penganggaran adalah penerapan anggaran yang berbasis prestasi kerja/hasil. Sistem anggaran berbasis kerja harus memerlukan kriteria pengendalian kinerja dan evaluasi. Pemerintah selaku pengelola dana publik agar dapat memenuhi akuntabilitas kiranya memperhatikan beberapa hal antara lain: anggaran, pengendalian akuntansi, dan sistem pelaporan.

Berdasarkan Undang-Undang Nomor 17 tahun 2003, penyusunan APBD dilakukan dengan mengintegrasikan program dan kegiatan masing-masing satuan kerja di lingkungan pemerintah daerah untuk mencapai sasaran dan tujuan yang ditetapkan. Suatu pencapaian tujuan anggaran akan terlaksana dengan baik bila didukung dengan tingkat kedisiplinan aparat pemerintah yang baik. Bagi aparatur instansi pemerintah, disiplin mencakup unsur-unsur ketaatan dan kesungguhan dalam menjalankan tugas dan kesanggupan berkorban, dalam arti mengorbankan kepentingan pribadi dan golongannya untuk kepentingan negara dan masyarakat.

Masalah-masalah yang berkaitan dengan penganggaran seperti partisipasi, kesenjangan anggaran, kinerja dan hal lainnya, telah menjadi fokus banyak peneliti karena masih banyak isu negatif dari masyarakat pada kinerja aparat pemerintah dalam melaksanakan anggaran yang seharusnya dilaksanakan sebagaimana mestinya. Dalam penelitian Said \& Cut (2011) mengungkapkan bahwa (1). Karakteristik tujuan anggaran di Pemerintah Kota Banda Aceh mempunyai pengaruh terhadap kinerja manajerial yang dijalankan. Penelitian Jallaudin dan Bahri (2009) menunujukkan 1. Partisipasi Anggaran mempengaruhi kinerja Aparat Pemerintah Daerah Kota Banda Aceh. 2. Kejelasan Tujuan Anggaran mempengaruhi kinerja Aparat Pemerintah Daerah Kota Banda 
Aceh. 3. Evaluasi Anggaran mempengaruhi kinerja Aparat Pemerintah Daerah Kota Banda Aceh. 4. Partisipasi Anggaran, Kejelasan Tujuan Anggaran, dan Evaluasi Anggaran secara simultan berpengaruh terhadap kinerja Aparat Pemerintah Daerah Kota Banda Aceh.

Masalah ini memberikan saran dalam menjalankan Kinerja Aparat Pemerintah Daerah tujuan anggaran, dan komitmen organisasi dalam melakukan kinerja manajerial pada Pemerintah Daerah, perlu adanya peningkatan dan pemahaman terhadap tujuan anggaran yang ingin di capai dan juga bagaimana keadaan organisasi yang dijalankannya guna mencapai kinerja yang maksimal dari instansi yang dipimpinnya. Untuk mencapai kinerja yang baik perlu dilakukan suatu pengawasan intern agar kegiatan/tindakan setiap individu/organisasi terawasi dan di pantau secara baik. Pengawasan intern menurut Mulyadi (2001), terdiri atas struktur organisasi, metode dan ukuran-ukuran yang dikoordinasikan untuk menjaga kekayaan organisasi, mengecek ketelitian dan keandalan data akuntansi, mendorong efisiensi, dan mendorong di patuhinya kebijakan manajemen. Maka dari itu pengawasan intern di harapkan dapat membantu para anggota organisasi dalam melaksanakan tanggung jawab secara efektif dan mencapai kinerja yang lebih baik. Dalam hal ini pemerintah harus terus berupaya untuk terus berbenah agar penggangaran kinerja tidak melenceng dari tujuan yang ada.

Daerah Khusus Ibukota Jakarta (DKI Jakarta) adalah ibu kota negara Republik Indonesia. Jakarta merupakan satu-satunya kota di Indonesia yang memiliki status setingkat provinsi. Jakarta terletak di Tatar Pasundan, bagian barat laut Pulau Jawa. Sebagai pusatbisnis, politik, dan kebudayaan, Jakarta merupakan tempat berdirinya kantor-kantor pusat BUMN, perusahaan swasta, dan perusahaan asing. Kota ini juga menjadi tempat kedudukan lembagalembaga pemerintahan dan kantor sekretariat ASEAN. Kinerja aparat pemerintah Jakarta masih menjadi pusat perhatian dari masyarakat karena setiap perubahan yang terjadi dapat terlihat jelas. Terdapat banyak isu yang berkaitan dengan kinerja aparat pemerintah Jakarta.

Diantara isu yang menjadi simptom tentang kondisi pengelolaan anggaran adalah Hasil Pansus Laporan Hasil Pemeriksaan Badan Pemeriksa Keuangan (LHP BPK) DPRD DKI atas temuan BPK RI terhadap anggaran DKI tahun 2014. yang dibacakan dalam sidang paripurna DPRD tanggal 7/10/2015. Ada enam temuan BPK yang menjadi permasalahan signifikan dan diselidiki oleh Pansus LHP BPK. Enam temuan itu di antaranya; pengawasan dan pengendalian kerja sama pemanfaatan aset tanah, pengadaan tanah rumah sakit, penetapan nilai penyertaan modal dan penyerahan aset Pemprov DKI, penyerahan aset Pemprov DKI berupa tanah, bangunan, dan blok apartemen, kelebihan pembayaran premi asuransi kesehatan dan administrasi pengelolaan dana operasional pendidikan (BOP).

\section{Telaah Teori dan Pengembangan Hipotesis}

Partisipasi sebagai suatu proses dimana bawahan terlibat dan memiliki pengaruh terhadap penyusunan anggaran Keterlibatan bawahan dianggap penting karena memiliki informasi yang lebih baik tentang keadaan area kerja mereka sehingga keterlibatan mereka diharapkan dapat memberikan informasi yang relevan dalam penyusunan anggaran serta komitmen untuk menjalankan anggaran yang telah ditetapkan (Nurzianti dan Anita, 2014:6). Menurut Anthony dan Govindarajan (2005) dalam Cahyadi dan Handoko (2010:174) menyatakan bahwa partisipasi anggaran adalah proses di mana pembuatan anggaran terlibat dan mempunyai mengaruh dalam penentuan besar anggaran.

Partisipasi merupakan suatu proses pengambilan keputusan bersama oleh dua pihak atau lebih yang mempunyai dampak masa depan bagi pembuat dan penerima keputusan dan mengarah pada seberapa besar tingkat 
keterlibatan aparat pemerintah daerah dalam menyusun anggaran daerah serta pelaksanaannya untuk mencapai terget anggaran tersebut (Saleh dan Heriadi, 2012:137).

Menurut Kenis (1979) dalam Munawar, dkk (2006:6) menemukan bahwa manajer memberi reaksi positif dan secara relatif sangat kuat untuk meningkatkan kejelasan tujuan anggaran. Manajemen tingkat atas dapat meningkatkan kepuasan kerja, menurunkan ketegangan kerja, dan memperbaiki anggaran yang dihubungkan dengan sikap, kinerja anggaran, dan efisiensi biaya manajer tingkat bawah secara signifikan meningkatkan kejelasan dan ketegasan tujuan anggaran mereka.

Tujuan anggaran adalah sebagai alat perencanaan, dengan adanya anggaran, organisasi tahu apa yang harus dilakukan dan ke arah mana kebijakan yang dibuat (Jalaluddin dan Bhari, 2009:4). Saleh dan Heriadi (2012:137) untuk tingkat daerah, kejelasan sasaran anggaran akan mempermudah aparat pemerintah daerah dalam meningkatkan kinerja karena apa yang ingin dicapai sudah terencana dengan baik. Anggaran pendapatan dan belanja daerah sebagai rencana kerja pemerintah daerah merupakan desain teknis pelaksana strategi untuk mencapai tujuan daerah.

Penemuan Kenis (1979) dalam Munawar, dkk (2006:6-7) adalah bahwa manajer memberi reaksi yang tidak menguntungkan untuk menggunakan anggaran dalam evaluasi kinerja dalam suatu gaya punitive (meningkatkan ketegangan kerja, menurunkan kinerja anggaran. Kecenderungannya, secara jelas hubungan antara variabel lemah. Lubis (2009:101) evaluasi anggaran adalah tindakan yang dilakukan untuk menelurusi penyimpanan atas anggaran ke departemen yang bersangkutan dan digunakan sebagai dasar untuk penilaian kinerja departemen. Hal ini akan mempengaruhi tiungkah laku, sikap dan kinerja manajer. Punitive approach dapat mengakibatkan rendahnya motivasi dan sikap yang negative, sedangkan supportive approach dapat mengakibatkan sikap dan perilaku yang positif.
Hanya kepuasan kerja dan motivasi anggaran ditemukan signifikan dengan hubungan yang agak lemah dengan umpan balik anggaran. Umpan balik mengenai tingkat pencapaian tujuan anggaran tidak efektif dalam memperbaiki kinerja dan hanya efektif secara marginal dalam memperbaiki sikap manajer. Penemuan ini gagal untuk menjelaskan hasil dari berbagai studi dengan hubungan umpan balik sikap, kinerja dalam task-goal setting (Kenis dalam Munawar, dkk,. 2006:6).

Munawar, dkk (2006:7) tujuan anggaran adalah range dari "sangat longgar dan mudah dicapai" sampai "sangat ketat dan tidak dapat dicapai”. Tujuan yang mudah dicapai gagal untuk memberikan suatu tantangan untuk partisipan, dan memiliki sedikit pengaruh motivasi. Tujuan yang sangat ketat dan tidak dapat dicapai, mengarahkan pada perasaan gagal, frustrasi, tingkat aspirasi yang rendah, dan tujuan partisipan. Lubis (2009:102) sasaran anggaran yang lebih ketat menimbulkan motivasi yang lebih tinggi, namun jika melewati batas limitnya maka pengetataan sasaran anggaran justru akan mengurangi motivasi.

Terdapat beberapa indikator untuk mengukur kinerja organisasi pemerintah adalah indikator kuantitas, kualitas dan efisiensi pelayanan; indikator motivasi para birokrat pelaksana monitor para kontraktor, melakukan penyesuaian budget memperhatikan kebutuhan masyarakat yang dilayani dan menuntut perbaikan pelayanan publik, serta adanya keadilan dalam memberikan pelayanan (Keban dalam Enceng dan El Anshori, 2012:400).

Istiyani (2009) menguji pengaruh karakteristik tujuan anggaran terhadap kinerja aparatur pemerintah daerah di kabupaten Temanggung. Teknik pengambilan sampel menggunakan cara purposive sampling. Metode ini dipilih karena sampel berdasarkan kriteria yaitu aparat Pemerintah Daerah yang menduduki jabatan pada level menengah ke bawah yang sekaligus sebagai pejabat pembuat komitmen artinya pejabat yang mempunyai kegiatan dalam 
penganggaan dan sekaligus sebagai pelaksana anggaran dan staf yang menangani dalam penyusunan anggaran. Sampel yang diolah dalam penelitian sebanyak 146 sampel dan diolah menggunakan program SPSS untuk menguji hipotesis. Penelitian ini menemukan bahwa dari lima variabel karakteristik tujuan anggaran, empat variabel (kejelasan tujuan, partisipasi, umpan balik dan kesulitan pencapaian tujuan) berpengaruh secara signifikan terhadap kinerja aparat Pemda di Kabupaten Temanggung, sedang variabel evaluasi anggaran tidak signifikan terhadap kinerja aparat Pemda di Kabupaten Temanggung.

Laoli (2012) menguji dan memperoleh bukti empiris mengenai pengaruh karakteristik tujuan anggaran (partisipasi anggaran, kejelasan tujuan anggaran, umpan balik anggaran, evaluasi anggaran, kesulitan tujuan anggaran) terhadap kinerja dengan sikap aparat sebagai intervening variabel pada Kabupaten Nias. Jenis data yang digunakan dalam penelitian ini adalah data primer. Alat analisis yang digunakan terdiri dari uji validitas dan reliabilitas instrument penelitian, uji faktor konfirmatori, uji asumsi klasik, analisis linear berganda dan analisis jalur. Hasil penelitian menunjukkan bahwa berdasarkan uji faktor konfirmatori, yang dapat diterima sebagai indikator pembentuk faktor karakteristik tujuan anggaran adalah partisipasi anggaran, kejelasan tujuan anggaran, umpan balik anggaran, dan kesulitan tujuan anggaran, sedangkan evaluasi anggaran tidak termasuk indikator pembentuk faktor karena tidak memenuhi syarat. Hasil penelitian ini juga menunjukkan bahwa karakteristik tujuan anggaran berpengaruh signifikan terhadap kinerja aparat Pemerintah Daerah Kabupaten Nias. Hasil penelitian ini juga menunjukkan bahwa karakteristik tujuan anggaran berpengaruh signifikan terhadap kinerja melalui sikap aparat pemerintah daerah.

Nurzianti dan Anita (2014) juga berhasil membuktikan pengaruh partisipasi anggaran, kejelasan tujuan anggaran, umpan balik anggaran, evaluasi anggaran dan kesulitan tujuan anggaran baik secara simultan maupun parsial terhadap kinerja pejabat Pemerintah Daerah di Kabupaten Aceh Besar.

Penelitian Maryanti (2002) mengujin pengaruh karakteristik tujuan anggaran terhadap sikap, perilaku, dan kinerja aparat pemerintahan daerah di Propinsi Nusa Tenggara Timur. Hasil penelitiannya menunjukkan bahwa evaluasi anggaran, umpan balik anggaran, dan kejelasan tujuan anggaran mempunyai pengaruh positif terhadap perilaku dan sikap aparat pemerintah di Propinsi Nusa Tenggara Timur. Hal ini menunjukkan bahwa evaluasi anggaran yang dilakukan aparat pemerintah daerah adalah cukup efektif, sehingga membuat mereka merasa sukses terhadap tujuan anggaran yang dibuat karena jelas dan spesifik. Variabel lain seperti partisipasi anggaran dan kesulitan tujuan anggaran tidak berpengaruh terhadap perilaku dan sikap aparatur pemerintah daerah Propinsi Nusa Tenggara Timur. Hal ini menunjukan bahwa perilaku dan sikap aparat pemerintah daerah Propinsi Nusa Tenggara Timur tidak dipengaruhi oleh partisipasi anggaran dan kesulitan tujuan anggaran, baik dalam hal menyiapkan usulan anggaran maupun mudah atau sulitnya anggaran yang dicapai. Umpan balik anggaran, evaluasi anggaran, dan kesulitan tujuan anggaran tidak berpengaruh terhadap kinerja aparatur pemerintah di Propinsi Nusa Tengara Timur, sedangkan partisipasi anggaran dan kejelasan tujuan anggaran berpengaruh signifikan negatif terhadap kinerja aparatur pemerintah daerah Propinsi Nusa Tenggara Timur. Hal ini menunjukkan anggaran yang dibuat tidak spesifik dan tidak jelas sehingga membuat kinerja aparat pemerintah daerah Propinsi Nusa Tenggara Timur menjadi rendah.

Penelitian Munawar (2006) merupakan pengembangan dari penelitian Maryanti (2002) yaitu karakteristik tujuan anggaran dengan variabel partisipasi anggaran, kejelasan tujuan anggaran, umpan balik anggaran, evaluasi anggaran dan kesulitan tujuan anggaran berpengaruh secara signifikan terhadap perilaku. 
Hal ini menunjukkan bahwa karakteristik tujuan anggaran secara keseluruhan menghasilkan pengaruh yang cukup kuat terhadap perilaku aparat pemerintah daerah kabupaten Kupang dalam rencana penyusunan anggaran. Variabel lain seperti karaketristik tujuan anggaran dengan variabel partisipasi anggaran, kejelasan tujuan anggaran, umpan balik anggaran, evaluasi anggaran, dan kesulitan tujuan anggaran secara keseluruhan menghasilkan pengaruh cukup kuat terhadap sikap Aparat Pemerintah Daerah Kabupaten Kupang dalam melaksanakan anggaran.

\section{Pengaruh Partisipasi Anggaran terhadap Kinerja Aparat Pemerintah Daerah}

Munawar (2006) bahwa variabel partisipasi anggaran berpengaruh secara signifikan terhadap kinerja aparat pemerintah daerah. Menurut Anthony dan Govindarajan (2005) dalam Cahyadi dan Handoko (2010:174) menyatakan bahwa partisipasi anggaran adalah proses di mana pembuatan anggaran terlibat dan mempunyai pengaruh dalam penentuan besar anggaran. Partisipasi anggaran sebagai suatu proses dalam organisasi yang melibatkan para manajer dalam penentuan tujuan anggaran yang menjadi tanggung jawabnya (Brownell, 1982).

Indikator dari partisipasi anggaran adalah pengaruh terhadap proses penyusunan rencana anggaran, aktif terlibat dalam proses atas penetapan "buttom up", penerimaan pendapatan atas penetapan perencanaan anggaran, keputusan akan rencana anggaran, pertemuan dengan staf untuk rencana anggaran, kontribusi dan partisipasi aktif dalam penyusunan rencana anggaran, pertimbangan pendapatan atas proses penyusunan anggaran, kendala waktu, menjadikan ketidaksesuaian anggaran terhadap daftar perencanaan. Berdasarkan penelitian sebelumnya dan uraian diatas, dapat ditarik sebuah hipotesis sebagai berikut :

$\mathrm{H}_{1}$ : Partisipasi anggaran berpengaruh terhadap kinerja aparat pemerintah daerah.

\section{Pengaruh kejelasan tujuan anggaran terhadap kinerja Aparat Pemerintah Daerah.}

Locke dan Schweiger (1979) bahwa kejelasan tujuan anggaran dapat meningkatkan kinerja manajerial, sedangkan kurangnya kejelasan mengarah pada kebingungan dan ketidakpuasan para pelaksana, yang berakibat pada penurunan kinerja. Manajer memberi reaksi positif dan secara relatif sangat kuat untuk meningkatkan kejelasan tujuan anggaran (Kenis, 1979).

Saleh dan Heriadi (2012:137) untuk tingkat daerah, kejelasan sasaran anggaran akan mempermudah aparat pemerintah daerah dalam meningkatkan kinerja karena apa yang ingin dicapai sudah terencana dengan baik. Anggaran pendapatan dan belanja daerah sebagai rencana kerja pemerintah daerah merupakan desain teknis pelaksana strategi untuk mencapai tujuan daerah. Berdasarkan penelitian sebelumnya yang menyatakan bahwa kejelasan tujuan anggaran berpengaruh terhadap kinerja aparat pemerintah daerah (Rahma Nurzianti dan Anita, 2014) serta berdasar teori yang telah diuraikan di atas, maka dirumuskan hipotesis sebagai berikut :

$\mathrm{H}_{2}$ : Kejelasan tujuan anggaran berpengaruh terhadap kinerja Aparat Pemerintah Daerah.

\section{Pengaruh evaluasi anggaran terhadap kinerja Aparat Pemerintah Daerah}

Munawar (2006) bahwa evaluasi anggaran berpengaruh terhadap perilaku aparat pemerintah daerah. Manajer memberi reaksi yang tidak menguntungkan untuk menggunakan anggaran dalam evaluasi kinerja dalam suatu gaya punitive (meningkatkan ketegangan kerja, menurunkan kinerja anggaran (Kenis, 1979). Punitive approach dapat mengakibatkan rendahnya motivasi dan sikap yang negative, sedangkan supportive approach dapat mengakibatkan sikap dan perilaku yang positif. Berdasarkan penelitian sebelumnya dan teori yang menyatakan bahwa evaluasi anggaran berpengaruh terhadap kinerja aparat pemerintah daerah Lubis (2009:101) di atas, maka dirumuskan hipotesis sebagai berikut: 
$\mathrm{H}_{3}$ : Evaluasi anggaran berpengaruh terhadap kinerja Aparat Pemerintah Daerah.

\section{Pengaruh Umpan Balik Anggaran terhadap kinerja Aparat Pemerintah Daerah.}

Istiyani, (2009:70) Indikator dari umpan balik di antaranya adalah umpan balik yang memadai sehubungan dengan prestasi dalam mencapai tujuan anggaran. Umpan balik yang berguna selama proses penyusunan rencana anggaran. Umpan balik dan evaluasi tentang kinerja pada akhir siklus/daur penyusunan rencana anggaran. Tidak memperoleh umpan balik terhadap kinerja dalam pencapaian tujuan anggaran. Umpan balik yang saya peroleh selama proses penyusunan rencana anggaran tidak berpengaruh terhadap kinerja. Perbaikan tingkah laku menurut umpan balik yang diterima, umpan balik pada akhir siklus penyusunan rencana anggaran tidak dapat digunakan dalam praktek.

Umpan balik mengenai tingkat pencapaian tujuan anggaran tidak efektif dalam memperbaiki kinerja dan hanya efektif secara marginal dalam memperbaiki sikap manajer. Penemuan ini gagal untuk menjelaskan hasil dari berbagai studi dengan hubungan umpan balik sikap, kinerja dalam task-goal setting (Kenis dalam Munawar, dkk,. 2006:6). Berdasarkan penelitian sebelumnya teori yang telah diuraikan di atas, maka dirumuskan hipotesis sebagai berikut :

$\mathrm{H}_{4}$ : Umpan balik anggaran berpengaruh terhadap kinerja Aparat Pemerintah Daerah.

\section{Pengaruh kesulitan tujuan aggaran terhadap kinerja Aparat Pemerintah Daerah.}

Hirst \& Lowy (1990) bahwa tujuan yang sulit menghasilkan kinerja yang lebih tinggi dibandingkan jika menetapkan tujuan spesifik yang sedang atau mudah, maupun tujuan yang bersifat umum. Tujuan anggaran adalah range dari "sangat longgar dan mudah dicapai" sampai "sangat ketat dan tidak dapat dicapai". Tujuan yang mudah dicapai gagal untuk memberikan suatu tantangan untuk partisipan, dan memiliki sedikit pengaruh motivasi. Tujuan yang sangat ketat dan tidak dapat dicapai, mengarahkan pada perasaan gagal, frustrasi, tingkat aspirasi yang rendah, dan tujuan partisipan (Munawar, dkk, 2006:7)

Lubis (2009:102) sasaran anggaran yang lebih ketat menimbulkan motivasi yang lebih tinggi, namun jika melewati batas limitnya maka pengetataan sasaran. Sedang indikator dari kesulitan pencapaian tujuan adalah tujuan anggaran sulit dicapai dan tidak ada masalah dalam mencapai tujuan anggaran (Istiyani, 2009:71).Berdasarkan penelitian sebelumnya teori yang telah diuraikan di atas, maka dirumuskan hipotesis sebagai berikut :

$\mathrm{H}_{5}$ : Kesulitan tujuan anggaran berpengaruh terhadap kinerja Aparat Pemerintah Daerah

\section{Metode}

Analisa dalam penelitian ini yaitu SKPD pemerintah DKI jakarta digunakan untuk meneliti pada populasi atau sampel tertentu, teknik pengambilan sampel pada umumnya dilakukan secara random, pengumpulan data menggunakan instrumen penelitian, analisis data bersifat kuantitatif statistik dengan tujuan untuk menguji hipotesis yang telah ditetapkan. Dimana target responden adalah Aparat Pemerintah Daerah yang menduduki jabatan, yang sekaligus sebagai pejabat pembuat komitmen, artinya pejabat mempunyai kegiatan dalam penggangaran dan sebagai pelaksana anggaran dan beberapa staf yang menangani dalam penyusunan anggaran di pemerintah Provinsi DKI Jakarta. Aparat pemerintah Provinsi DKI Jakarta yang kami teliti terdiri dari kantor Sekretaris Daerah meliputi Asisten, Biro, Dinas, Badan, kota Administrasi, Kabupaten kepulauan seribu, 1 Sekretariat Dewan/DPRD dan Badan Layanan Umum (BP.Transjakarta).

Variabel bebas merupakan variabel yang mempengaruhi atau yang menjadi sebab perubahannya atau timbulnya variabel terikat (Sugiyono, 2010:59). Variabel bebas dalam penelitian ini adalah Partisipasi Anggaran (X1), Kejelasan Tujuan Anggaran (X2), Evaluasi 
Anggaran (X3), Umpan Balik Anggaran (X4), Kesulitan Tujuan Anggaran (X5) dan Pengawasan Pelaksanaan Angaran (X6).

Teknik pengumpulan data dalam penelitian ini dilakukan dengan Kuesioner. Teknik pengumpulan data yang dilakukan dalam penelitian ini adalah dengan menggunakan kuesioner. Kuesioner adalah teknik pengumpulan data yang dilakukan dengan cara memberikan seperangkat pertanyaan atau pernyataan tertulis kepada responden untuk dijawabnya. Teknik pengumpulan data ini cocok digunakan jika jumlah responden cukup besar dan tersebar di wilayah yang luas (Sugiyono, 2010:199).

Analisis data pada penelitian ini dilakukan dengan menggunakan analisis regresi berganda. Analisis regresi ganda digunakan untuk meramalkan bagaimana keadaan (naik-turunnya) variabel terikat, bila dua atau lebih variabel bebas sebagai prediktor dimanipulasi (dinaikturunkan nilainya). Jadi analisi s regresi ganda akan dilkukan jika jumlah variabel bebasnya minimal dua. Rumus regresi berganda adalah sebagai berikut (Sugiyono, 2010:277):

$$
\begin{aligned}
& \mathrm{Y}=\mathrm{a}+\mathrm{b}_{1} \mathrm{X}_{1}+\mathrm{b}_{2} \mathrm{X}_{2}+\mathrm{b}_{3} \mathrm{X}_{3}+\mathrm{b}_{4} \mathrm{X}_{4}+\mathrm{b}_{5} \mathrm{X}_{5} \\
& \text { Keterangan: } \\
& \mathrm{Y}=\text { variabel Kinerja Aparatur Pemer- } \\
& \text { intah Daerah } \\
& \mathrm{a}=\text { konstanta, nilai } \mathrm{Y} \text { apabila } \mathrm{X}=0 \\
& \mathrm{~b}=\text { koefisien regresi linear berganda } \\
& \mathrm{X} 1=\text { Partisipasi Anggaran } \\
& \mathrm{X} 2=\text { Kejelasan Tujuan Anggaran } \\
& \mathrm{X} 3=\text { Evaluasi Anggaran } \\
& \mathrm{X} 4=\text { Umpan Balik Anggaran } \\
& \mathrm{X} 5=\text { Kesulitan Tujuan Anggaran }
\end{aligned}
$$

\section{Hasil Penelitian dan Pembahasan}

Penelitian ini bertujuan untuk menguji pengaruh partisipasi, kejelasan tujuan, evaluasi, umpan balik, dan kesulitan pencapaian tujuan terhadap kinerja aparatur pemerintah daerah. Hasil pengujian hipotesis diawali dengan uji validitas dan reliabilitas untuk menguji kualitas instrumen penelitian. Pengujian validitas instrumen dengan menggunakan software statistic, nilai validitas ditunjukan pada kolom Corrected Item Total Correlation. Jika angka korelasi yang diperoleh lebih besar dari pada angka kritik (r-hitung $>$ r-tabel) maka instrumen tersebut dikatakan valid. Berdasarkan uji validitas dapat disimpulkan bahwa seluruh item pertanyaan untuk mengukur masingmasing variabel penelitian dinyatakan valid. Berdasarkan data yang di olah menunjukan bahwa item pertanyaan variabel-variabel penelitian mempunyai nilai korelasi (r) yang lebih besar dari r-tabel yaitu 0,3202, dengan demikian semua item pertanyaan variabelvariabel penelitian valid dan dapat digunakan pada analisis selanjutnya.

Pengujian Reliabilitas dilakukan untuk menunjukan sejauh mana suatu alat pengukur dapat dipercaya. Menurut Ghazali (2006) dalam bukunya Nunnally, 1960, suatu variabel dikatakan reliabel jika memberikan nilai Cronbach's alpha $>0,6$. Jawaban kuisioner penelitian tersebut dinyatakan rreliabel karena masing-masing pertanyaan dijawab secara konsisten. Berdasarkan hasil pengujian data menunjukan bahwa nilai cronbach's alpha dari masing-masing variabel yang diteliti lebih besar dari 0,6. Hal ini menunjukan bahwa instrumen tersebut reliabel. Berdasarkan data tersebut di atas, variabel partisipasi anggaran, kejelasan tujuan anggaran, evaluasi anggaran, umpan balik anggaran, kesulitan pencapaian tujuan anggaran dan variabel kinerja sudah memenuhi kriteria validitas dan reliabilitas.

Dari pengujian hipotesis diketahui bahwa koefisien korelasi (R) sebesar 0,858 . Nilai tersebut menunjukan bahwa hubungan antar variabel independent (partisipasi anggaran, kejelasan tujuan anggaran, evaluasi anggaran, umpan balik anggaran dan kesulitan pencapaian tujuan anggaran) dinyatakan memiliki hubungan yang kuat dengan nilai korelasi mendekati satu(1) yaitu sebesar 0,858 atau $85,8 \%$. Sedangkan nilai koefisien determinasi ( $R$ square) menghasilkan angka sebesar 0,736 yang berarti bahwa kinerja 
aparat pemerintah daerah (Y) di pemerintahan provinsi DKI Jakarta dapat dijelaskan oleh variabel-variabel independen partisipasi anggaran (X1), kejelasan tujuan anggaran (X2), evaluasi anggaran (X3), umpan balik anggaran (X4) dan kesulitan pencapaian tujuan anggaran (X5) atau sebesar 73,6\%. Sedangkan sisanya sebesar $26,4 \%$ dijelaskan oleh faktor-faktor lain yang tidak terdapat dalam penelitian ini.

Hipotesis dalam penelitian ini adalah terdapat pengaruh antara partisipasi anggaran, kejelasan tujuan anggaran, evaluasi anggaran, umpan balik anggaran dan kesulitan pencapaian tujuan anggaran terhadap kinerja aparat pemerintah daerah di pemerintah provinsi DKI Jakarta. Pengujian uji kesesuaian dilakukan untuk menentukan kelayakan suatu model regresi, karena variabel penelitian lebih dari satu variabel maka kelayakan tersebut dapat dilihat dari nilai adjusted $R$ Square. Rangkuman hasil pengujian sebagaimana table berikut.

Tabel 1. Hasil Pengujian

\begin{tabular}{lrrrr}
\hline Keterangan & B & $\begin{array}{c}\text { Std. } \\
\text { Error }\end{array}$ & t-hitung & Sig. \\
\hline Partisipasi & $-0,155$ & 0,131 & $-1,180$ & 0,246 \\
Kejelasan & 0,372 & 0,152 & 2,443 & 0,020 \\
Tujuan & 0,886 & 0,135 & 6,555 & 0,000 \\
Evaluasi & 0,850 \\
Umpan & 0,555 & 0,129 & 4,301 & 0,000 \\
Balik & & & & \\
Kesulitan & 0,082 & 0,285 & 0,287 & 0,776 \\
$\begin{array}{l}\text { Pencapaian } \\
\text { Tujuan }\end{array}$ & $0,0,736$ & & & \\
$\begin{array}{l}\text { R-Square } \\
\text { Adjusted }\end{array}$ & 0,698 & & & \\
$R$-Square & & & & \\
F-hitung & 19,531 & & & \\
Sig. F & 0.000 & & & \\
\hline
\end{tabular}

Berdasarkan model uji kelayakan, dapat disimpulkan bahwa korelasi atau hubungan antara kinerja aparat pemerintah daerah dengan partisipasi anggaran, kejelasan tujuan anggaran, evaluasi anggaran, umpan balik anggaran dan kesulitan pencapaian tujuan anggaran terdapat hubungan yang erat. Variasi atau perubahan dalam variabel kinerja aparat pemerintah daerah dapat dijelaskan oleh variabel partisipasi anggaran, kejelasan tujuan anggaran, evaluasi anggaran, umpan balik anggaran dan kesulitan pencapaian tujuan anggaran sedangkan sisanya dijelaskan oleh sebab-sebab lain yang tidak masuk dalam penelitian ini.

Berdasarkan hasil uji $t$ atau pengujian variabel, didapat variabel independen, yaitu partisipasi anggaran tidak berpengaruh terhadap kinerja aparat pemerintah darah, variabel kejelasan tujuan anggaran berpengaruh terhadap kinerja aparat pemerintah daerah, variabel evaluasi anggaran berpengaruh terhadap kinerja aparat pemerintah daerah, variabel umpan balik anggaran berpengaruh terhadap kinerja aparat pemerintah daerah dan variabel kesulitan pencapaian tujuan anggaran tidak berpengaruh terhadap kinerja aparat pemerintah daerah.

Sedangkan berdasar hasil uji $\mathrm{F}$ dapat disimpulkan bahwa semua variabel independen yaitu partisipasi anggaran, kejelasan tujuan anggaran, evaluasi anggaran, umpan balik anggaran dan kesulitan pencapaian tujuan anggaran berpengaruh terhadap kinerja aparat pemerintah daerah di provinsi DKI Jakarta.

Penelitian ini sejalan dengan penelitian yang dilakukan oleh Mutmainah dan Ikhsan (2013) menyatakan bahwa karakteristik tujuan anggaran berpengaruh positif terhadap kinerja manajerial. Hal ini berarti bahwa semakin baik karakterisitk tujuan anggaran akan semakin meningkat kinerja aparat pemerintah daerah.

\section{Simpulan, Keterbatasan, dan Implikasi Hasil Penelitian}

Tujuan penelitian ini adalah untuk mengetahui pengaruh partisipasi anggaran, kejelasan tujuan anggaran, evaluasi anggaran, umpan balik anggaran dan kesulitan pencapaian tujuan anggaran terhadap kinerja aparat pemerintah daerah. Berdasarkan hasil pengujian, partisipasi anggaran dan kesulitan pencapaian tujuan tidak berpengaruh terhadap kinerja aparat pemerintah daerah. Kejelasan tujuan anggaran, 
umpan balik dan evaluasi anggaran berpengaruh positif terhadap kinerja aparat pemerintah daerah.

Penelitian ini memerlukan responden yang lebih berkarakteristik pengelolaan anggaran sesuai dengan backgroud pendidikan serta Penelitian ini hanya terbatas pada partisipasi anggaran, kejelasan tujuan anggaran, evaluasi anggaran umpan balik anggaran dan kesulitan pencapaian tujuan anggaran, tidak menggunakan aspek lain sehingga hasil penelitian tidak dapat menggambarkan kinerja Aparat Pemerintah Daerah secara keseluruhan.

Pembuat kebijakan/egulator untuk mempermudah aspek-aspek penelitian sehingga penelitian selanjutnya dapat memperkecil gap, sebaiknya faktor-faktor yang lain selain variabel dalam penelitian ini dipertimbangkan dengan menentukan segala kebijakan yang terkait. Peneliti selanjutnya sebaiknya menambah jumlah sampel yang diambil dengan cakupan Pemerintah Daerah yang lebih luas dengan responden yang lebih berkarakteristik pengelolaan anggaran sesuai dengan latar belakang pendidikan dan pengalaman kerja. Penelitian selanjutnya juga dapat menambahkan faktor anggaran lainnya seperti motivasi kerja, etika dan variabel lainnya. Agar penelitian selanjutnya dapat lebih terarah sebaiknya mempertimbangkan beberapa hasil penelitian yang telah ada untuk mengembangkan dan merumuskan teori yang mendukung. Sebaiknya, praktisi pemerintah daerah melakukan kebijakan upgrade kapabilitas pengelola anggaran serta melakukan pengawasan melekat yang terarah tujuan dan terpadu terhadap proses anggaran yang dimulai dari tahap perencanaan hingga monitoring dan evaluasinya.

\section{Daftar Referensi}

Arikunto, Suharsimi. (2010). Prosedur Penelitian: Suatu Pendekatan Praktik. Jakarta: Rineka Cipta.

Cahayadi, Riandy S., Handoko, Jesica. (2010). Pengaruh Komitmen Organisasi, Gaya Kepemimpinan, Dan Ketidakpastian Lingkungan Terhadap Hubungan Partisipasi Anggaran Dengan Kinerja Manajerial. Jurnal Akuntansi Kontemporer Vol. 2, No. 2. Hal:171-190.

Enceng., Anshori, Yulio Tirtariandi El. (2012). Pengaruh Motivasi Kerja Dan Kinerja Aparatur Pemerintah Kecamatan Terhadap Kualitas Pelayanan Masyarakat (Studi Di Kantor Kecamatan Jatinangor Kabupaten Sumedang). Jurnal Ilmiah Administrasi Publik dan Pembangunan Vol. 13, No. 1. Hal:396-407.

Ghozali, Imam. (2013). Aplikasi Analisis Multivariate dengan Program IBM SPSS 21 Update PLS Regresi. Semarang: Badan Penerbit Universitas Diponegoro.

Istiyani. (2009). Pengaruh Karakteristik Tujuan Anggaran Terhadap Kinerja Aparatur Pemerintah Daerah (Studi Empiris pada Pemerintah Kabupaten Temanggung). Tesis. Universitas Sebelas Maret. Surakarta Laoli, Victorinus. (2012). Pengaruh Karakteristik Tujuan Anggaran Terhadap Kinerja Dengan Sikap Aparat Pemerintah Daerah Sebagai Variabel Intervening (Studi Empiris Pada Pemerintah Kabupaten Nias). Tesis. Univeristas Sumatera Utara. Medan.

Lubis, Henny Zurika. (2009). Pengaruh Budgetary Goal Characteristics Terhadap Kinerja Manajerial Dengan Dimoderasi Budaya Paternalistik (Studi Empiris Perguruan Tinggi Swasta di Medan). Jurnal Riset Akuntansi dan Bisnis Vol. 9. No. 2. Hal:98-110.

Mardiasmo. (2006). Pengukuran Kinerja Pemerintah Daerah. Yogyakarta: UAD Press kerja sama Fakultas Ekonomi UAD. 
Munawar, Irianto, Gugus., N. (2006). Pengaruh Karakteristik Tujuan Anggaran Terhadap Perilaku, Sikap, Dan Kinerja Aparat Pemeirntah Daerah Di Kabupaten Kupang. Simposium Nasional Akuntansi 9 Padang 23-26 Agustus 2006. Hal:1-45.

Nurzianti, Rahma., A. (2014). Pengaruh Karakteristik Tujuan Anggaran Terhadap Kinerja Aparat Pemeirntah Daerah Di Kabupaten Aceh BESAR. Jurnal Dinamika Akuntabilitas Dan Bisnis Vol. 1, No. 1. Hal:59-71.

Sadjiarto, Arja. (2000). Akuntabilitas Dan Pengukuran Kinerja Pemerintahan. Jurnal Akuntabilitas \& Keuangan Vol. 2, No. 2. Hal:138-150.

Saleh, Muhammad., H. (2012). Pengaruh Karakteristik Sasaran Anggaran Terhadap Kinerja Aparat Pemerintah Daerah Pada Kabupaten Aceh Singkil. Jurnal Akuntansi dan Keuangan Vol. 2, No. 2. Hal:135-144.

Sardjito, Bambang., M. Osmad. (2007). Pengaruh Partisipasi Penyusunan
Anggaran Terhadap Kinerja Aparat Pemerintah Daerah: Budaya Organisasi Dan Komitmen Organisasi Sebagai Variabel Moderating. Simposium Nasional Akuntansi X. Unhas Makassar 26-28 Juli 2007. Hal:1-24.

Sudarmanto. (2009). Kinerja dan Pengembangan Kompetensi SDM. Yogyakarta: Pustaka Pelajar.

Sugiyono. (2010). Metode Penelitian Bisnis (Pendekatan Kuantitatif, Kualitatif, dan R\&D). Bandung: Alfabeta.

Utami, Yulenta Bayangsari. (2015). Pengaruh Pendidikan dan Pelatihan Terhadap Kinerja Aparatur Pemerintah Di Sekretariat Daerah Kabupaten Bengkayang. Jurnal Ilmu Pemerintahan Vol. 4, No. 3. Hal:1-18.

Verasvera, Febrina Astria. (2016). Pengaruh Anggaran Berbasis Kinerja Terhadap Kinerja Aparatur Pemerintah Daerah (Studi Kasus Pada Dinas Sosial Provinsi Jawa Barat). Jurnal Manajemen Vol. 15, No. 2. Hal:137-162. 